* ICFBE 2020

The $4^{\text {th }}$ International Conference on Family Business and Entrepreneurship

\title{
THE HIGH PERFORMANCE WORK EVIRONMENT AND EMPLOYEE ENGAGEMENT ON MILLENIALS GENERATION WORKING AT GREEN BUSINESS ORGANIZATION
}

\author{
P. Prasetyanto ${ }^{1}$, N. K. Darmasetiawan ${ }^{2}$, J. L. E. Nugroho ${ }^{3}$ \\ University of Surabaya, noviatykds@staff.ubaya.ac.id
}

\begin{abstract}
:
This research analyzes the influence of high performance work environment and employee engagement on millennials working in companies that implement green business. The type of research used mixed methods, i.e. quantitative methods that are equipped with qualitative methods. Variables tested are based on the dimensions expressed. Taking data using questionnaires, the study respondents were millennials working in the green business organization.

The purpose of this study is to look at the influence of high performance work environment factors on employee engagement in millennials working in companies that implement green business.

The results showed that there is a significant influence between high performance work factors on employee engagement in millennials working in green business organizations.
\end{abstract}

Keywords: high performance work environment, employee engagement, green business organization.

\section{Introduction}

Millennials enjoy new opportunities and develop skills. Like other generations, the millennial generation demands a work environment, has high self-confidence and tends to be optimistic (Huntlay, Smola \& Sutton, in Wong et al, 2008). Millennials also said to be responsible, and have idea in decisions and actions (McCrindle \& Hooper, in Wong et al, 2008). In addition, it was also explained that the millennial generation has the ability to see problems and opportunities from a new perspective, and is more accepting of diversity and likes working in teams than previous generations (Myers \& Sadaghiani, 2010). Gladwell et al (2010) According to Gladwell, the millennial generation appreciate learning and development opportunities, credible and positive role models, and a balance between life and work (Kapoor \& Solomon, 2011). 
Macey et al. (2009) stated that employee engagement is important in creating shareholder value in an organization, especially in modern organizations with shifting organization to the millennial generation as employees or business people, more than just commitment, even though there are many assumptions that the millennial generation who become employees lack employee engagement, lack loyalty and work ethic. Individuals in this generation appear comfortable with change and tend not to see job security as an important factor in the workplace (N.I Ardiansyah \& N.K., Darmasetiawan, 2019). As an employee, the millennial generation enjoys new opportunities and wants to always develop their skills. On the other hand, Macey (2009) states that a high performance work environment will encourage employee engagement feeling. And employee engagement feeling will affect employee engagement behavior.

Green Business organization is a business organization that is run with a vision to meet the needs of society, but also more preserving the environment. This business maintains the triple bottom line, namely economic sustainability (profit), ecological sustainability (planet), and socio-cultural sustainability of people (including human rights). (Koester, 2010).

PT. A, PT. B, PT. C, and PT. D who have implemented Green Business practices in their organization. One thing that is emphasized in the Green Business Organization is the effort to maintain sustainability as a whole.

Gil Friend (2009) defines sustainability in green business as "living and doing business in ways that don't erode the potential for future generations - commonly refers to the triple bottom line (TBL) or economic, environmental, and social benefits".

Robert (2010) explain in detail that:

"The sustainable organization must generate acceptable levels of economic performance, or it will not survive. It must also nurture social performance in its interaction with customers, suppliers, consumers, and other interest groups. Survival is also contingent on the firm's ability to achieve acceptable levels of environmental performance throughout the supply cycle from raw material procurement to post consumption disposal."

The high performance work environment proposed by Macey will be able to build principles for engagement, which include the capacity to engage, motivation to engage, freedom to engage, and know how to engage. (Macey, 2009).

Furthermore, Macey (2009) states that a high performance work environment will create employee engagement feelings. Employee engagement feeling includes feeling of urgency, feeling of being focused, feeling of intensity, and feeling of enthusiasm.

And furthermore, it can be said that employee engagement feeling will be able to create employee engagement behavior.

Hence, the following are research questions that will be answer in this study: (1) How does high performance work environment affect employee engagement feelings with millennial generation employees who work in green business organizations?; (2) How do employee engagement feelings create employee engagement behavior among millennial generation employees who work in green business organizations?

\section{Literature Review}

\section{High Performance Work Environment}

The Work Environment is one of the most important things for a company to pay attention to. The work environment is something that is in the worker's environment that can affect a person's work processes, such as temperature, humidity, lighting, and other things (Isyandi, 2004).

Simajuntak (2003), The work environment can be interpreted as something that employees live in, such as the environment where a person works, work methods, which can then affect their work. Saydam (2000), The work environment is a work infrastructure that is around employees who are carrying out work and can affect the results of the work.

Based on the definition, the work environment is very important for companies to pay attention to. although it does not have a direct impact on the processes in the company, it is considered to have an impact on the psychological and physical condition of workers / employees. 
A high performance work environment is a work environment that supports creativity, collaboration, and society which has become a necessity in recent years. High performance work environment supports the existence of teams produce quality products and services using innovative techniques. They tend to collaborate more effectively than other groups of people. In these high-performance environments, people trust one another, feel empowered to make changes and experience high levels of job satisfaction. Employees with high morale miss work less frequently and function more productively and cost-effectively. Describing the characteristics of a high-performance workplace involves listing the actions taken by leaders to establish an effective team, and the results thereby achieved. High performance work environments are characterized by setting clear goals, maintaining open communication, valuing diversity, and fostering collaboration. A high performance work environment will create four principles for the occurrence of capacity to engage, motivation to engage, freedom to engage, and know how to engage (Macey, 2009).

\section{Employee Engagement}

Employee engagement is a stable psychological state and is the result of interactions between an individual and the workplace environment (Thomas, 2007). According to Luthans and Peterson, engagement occurs when a person consciously has emotions that are connected to other people (Nusantria, 2011). Kahn (1990) states that the construct of engagement is multidimensional, which is not only about emotionally but also physically and cognitively. According to Macey et al (in Armstrong, 2017), engagement is an individuals goal and focus shown through work initiative, adaptability, effort, and persistence in achieving organizational goals.

Employee engagement is a condition in which employees pay full attention to their work. Engagement also defined as a positive attitude, which is shown by employees towards the organization so that they give their best efforts to doing their job.

Furthermore, Macey (2009) states that employee engagement will begin with the employee engagement feeling, and then employee engagement feeling will encourage employee engagement behavior.

Individual employee engagement feeling is felt in the form of feeling of urgency, feeling of being focused, feeling of intensity, and feeling of enthusiasm. Furthermore, employee engagement feeling will be shown in the form of employee engagement behavior. Employees who have employee engagement behavior will show persistence behavior, proactive, trying to expand the role (role expansion), and adaptability.

\section{Millenial Generation Worker}

Generations are an identified group, usually divided into years of birth and significant life events at the critical development stage experienced by a particular generation. Generational groups include those who share historical or social life experiences that influence the way individuals in that generation develop and differentiate one generation group from another (Wong et al, 2008).

Y Generation members include individuals born in the range 1982 to 2000 (Wong et al, 2008). Current Y generation labels include millennials, nexters, www generation, digital generation, E generation, echo generation, and Net generation (Tolbize, 2008). Hart (in Tolbize, 2008) said that the millennial generation has grown up with technology and made technology a part of life. N.I, Ardiansyah \& N.K., Darmasetiawan (2018) illustrates that the millennial generation lacks loyalty and work ethic.

Individuals in this generation appear comfortable with change and tend not to see job security as an important factor in the workplace. As employees, millennials enjoy new opportunities and develop skills. The millennial generation demands a work environment, has 
high self-confidence and tends to be optimistic (Huntlay, Smola \& Sutton Sitat in Wong et al, 2008). Millennials are also said to be responsible, and have idea in decisions and actions (McCrindle \& Hooper in Wong et al, 2008). In addition, it was also explained that the millennial generation has the ability to see problems and opportunities from a new perspective, and is more accepting of diversity and likes working in teams than previous generations (Myers \& Sadaghiani, 2010). According to Gladwell et al (2010), the millennial generation appreciate learning and development opportunities, credible and positive role models, and a balance between life and work (in Kapoor \& Solomon, 2011).

\section{Green Business Organization}

Ernst \& Young (2008) argues that green business is a relatively new thing, a term that can be interpreted in many different ways by different people or organizations. What one organization considers as "green" may not be the same as another. The core of a green business is its focus on sustainability, in terms of the environment and resources (Ernst \& Young, 2012). According to Eric Koester (2010), in his book entitled Green Entrepreneur Handbook, it is written that:

"In general, green business are just like any other business in that they must create sufficient profits to continue to operate. The difference lies in what else green business concern themselves with - weighing the value of sustainability and human capital, for instance."

Green business requires a balanced commitment between profitability (finance), sustainability and humanity (Eric Koester, 2010). Gil Friend (2009) defines a green business as a business that: (1) Reduces negative environmental impacts; (2) Complies with environmental regulations; (3) Has a slick green marketing campaign; (4) Publishes a Corporate Social Responsibility; (5) Has a good environmental management systems; (6) Is ISO 14001 or otherwise "green" certified; (7) Can sustain its operations into the future indefinitely; (8) Enriches the world in which it operates. Therefore, it can be said that green business does not only focus on the environment, but includes sustainability as a whole.

\section{High Performance Work Environment, Employee Engagement Feeling, and Employee} Engagement Behavior on Millenial Generation Working at Green Business Organization

Basically, a high performance work environment supports a creative, collaborative and socially oriented work environment. The work environment has been continuously improved in recent years. While the previous generation distinguished clearly between the social and work environment, many believed that the work environment was enhanced by fostering a professionals community with the same way of thinking. Millennials have redefined how work can be done and pushed the company's business forward.

In line with statement of Myers \& Sadaghiani (2020), that the millennial generation has the ability to see problems and opportunities from a new perspective, and is more accepting of diversity and likes working in teams than previous generations, a high performance work environment is also a supportive work environment. there is creativity, collaboration, and social, Likewise, a green business organization is also a work place where there are (1) clear goal settings, where effective leaders communicate a clear vision and establish realistic goals, ensuring that team members have adequate training; (2) maintaining open communication, in a high-performance workplace, leaders communicate regularly with subordinates to provide direction on what tasks need completion; (3) valuing diversity, recognizes the value that each team member brings, encourages each to contribute ideas, methods and opinions, even if they differ from his own, a positive work environment makes everyone on the team feel empowered to make suggestions and not fear reprisals. Each employee in a high-performance workplace feels valued. This contributes to high 
productivity; (4) Fostering Collaboration, on high-performance teams, team members rely on each other for their individual skills and experience. When everyone gets rewarded consistently, these teams tend to work well together. With a sense of belonging and purpose, employees tend to work harder towards fixing difficult problems, handling customer complaints and maintaining a competitive edge for the company in a complex global marketplace. Encouraging team members to develop their skills and knowledge fosters an atmosphere of growth and development that benefits not only the company, but the employee as well.

On the other hand, a green business organization is also an organization that has managed to become a high performance work environment to maintain overall sustainability. Furthermore, Macey (2009) states that a high performance work environment will affect employee engagement feeling, and then employee engagement feeling will encourage employee engagement behavior.

\section{Research Method}

This research entails a focused on the topic of high performance work environment and employee engagement. The research used mixed methods, i.e. quantitative methods that are equipped with qualitative methods. It is a combination of explanatory and basic research with the purpose to understand the existed of high performance work environment and employee engagement feeling, employee engagement feeling and employee engagement behavior in employee engagement and their effects and then used phenomenological approach, a qualitative descriptive research, where the researcher knows the position at the time of data collection in field, and become the data interpreter (Moleong, 2011), to analyze this topic through the experience, opinion, thoughts, and feelings of the employee of PT. A, PT. B, PT. $\mathrm{C}$, and PT. D who has implemented Green Business practices in the organization. It is also supported by various theories of performance work environment, employee engagement feeling, employee engagement behavior in employee engagement. The sampling technique used in this research is purposive sampling, that is sampling technique from data source with certain consideration. (Sugiyono, 2013).

Data collection techniques for kuantitatif method used kuesioner and kualitatif method used in-depth interviews. Data analysis techniques for quantitative method using. The data obtained from the questionnaire were selected first and then processed and analyzed using SPPS version 2.4. The results of this processing are then reprocessed using AMOS to provide a deeper analysis, in accordance with the objectives and benefits of this study. Data processing used in this research begins with a validity test and a reliability test.

Data analysis techniques for qualitative method using (1) data reduction, data collected from the field in the form of results in depth interview and observation, recorded in detail and thorough, then summarized, selected key points, focus on the things that are important and sought the theme and the pattern. After that was done (2) display data after the data was reduced, then the next step is to perform the presentation of data. The presentation is done in the form of a brief description, making the chart, the relationship between categories, flowchart, in this study used narrative text. And the last step done (3) conclusion drawing/ verification is the withdrawal of conclusions and verification (according to Miles and Huberman in Soegiyono, 2013).

\section{Results and Discussion}

From the results of quantitative research that has been done, it has been proven that (1) High performance work environment affects employee engagement feelings for millennial 
generation employees who work in green business organizations in a significant positive manner and (2) Employee engagement feeling can create employee engagement behavior among employees millennial generation who work in green business organizations are positively significant.

Furthermore, from the results of the qualitative analysis, it was found that according to one person who was a millennial employee, but already had a position as a senior manager at PT. A, said that PT. A is a company that is included in the green business organization category. Companies that apply the green company concept will strive to consistently create business growth in a sustainable manner, have high performance demands, through a green business that serves as a means of promotion. This is in line with the principle that a high performance work environment is marked by setting clear goals. Furthermore, he said that it is in line with the green company concept applied at PT. A, This company also accommodates green companies starting from the formulation of the company's vision and mission, strategic policies, business processes, to marketing, it also involves partners who care about the principles of green company, which includes the triple $\mathrm{P}$ (people, profit, planet), thus creating a green culture in PT. A, including the social and business aspects. In line with what was conveyed by millennial employees from PT. A, it can be said that these conditions are in accordance with a high performance work environment, namely a work environment that supports collaboration, and is social to achieve profitability. Judging from the responses of employees who implementing the company's vision and mission, employees including millennial employees show enthusiasm, high initiative and care deeply about company concerns, through creative ideas put forward by employees for the progress of PT. A. This is also supported by the results of qualitative research on millennial employees of PT. A who works as a production employee, that the employee is always passionate about carrying out an energy efficient production process, does not pollute the surrounding environment, carries out the production process optimally to produce products that are aware of the environment. Meanwhile, the third millennial employee of PT. A, who was interviewed, felt very excited to be involved in supporting the company by suggesting the idea of organizing a CSR program run by PT. A, namely the idea of implementing CSR in the form of education about the environment and biodiversity from an early age at the primary to secondary school level, to the university. This is according to millennial employees who work at PT. This A will make the vision of company $\mathrm{X}$ more realizable.

Millennial employees from PT. B, said that PT. B has a clear direction, namely caring for environmental, economic, and social sustainability as a conscious unit in running a better life. According to millennial employees from PT. B, what is the company's vision has been internalized, so that in line with this vision, Millennial Employees from PT. This B voluntarily and with full awareness carries out his work to produce something of quality at an affordable price, so that the sustainability and existence of the company can run.

The results of qualitative research on millennial employees who work at PT. C, said that PT. C has internalized all employees, so that it is in line with the green business program conducted by PT. C. The employee voluntarily changes his behavior to be more environmentally friendly in accordance with the company's vision. Meanwhile, from an interview conducted with one of the millennial employees of PT. D, who is also one of the companies implementing green business, it is known that the employee is trying to develop his role as a socio intrapreneur, which is also a form of role expansion. This is consistent with statement of Macey (2009), that one of the characteristics of employees who have employee engagement is that one of them wants to take on role expansion, in addition to showing persistence and proactive behavior.

Therefore, the results of the qualitative research were conducted, millennial employees who work in green business organizations, showed employee engagement feeling, namely the feeling of urgency, feeling of being focused, feeling of intensity, and feeling of enthusiasm. Furthermore, this condition also shows employee engagement behavior. Millennial employees who work in green business organizations show employee engagement behavior in the form of persistence, proactive, and adaptability behavior in accordance with the demands of existing developments. 


\section{Conclusion and Implications}

From the above discussion it is concluded (1) High performance work environment affects employee engagement feelings among millennial generation employees who work in green business organizations positively and significantly (2) Employee engagement feeling can create employee engagement behavior among millennial generation employees who work in a green business organization it is positively significant.

Meanwhile, from the analysis of quantitative data, it is known that companies that are run as green business organizations are run as companies that are in line with companies that are high performance work organizations. As stated by Macey (2009) that high performance work environment will affect employee engagement feeling, which then employee engagement feeling will encourage employee engagement behavior.

\section{References}

Amstrong, M. 2017. Handbook of Human Resource Management Practice, Thirteenth Edition, London, Kogan Page.

Eric Koester. 2010. Green Entrepreneur Handbook: The Guide to Building and Growing a Green and Clean Business. Taylor and Francis Group, Boca Raton.

Ernst \& Young. 2011. Employee engagement: An exaimation of antecedent and outcome variables. Human Resources Development International 14(4).

Isyandi, B. 2004. Manajemen Sumber Daya Manusia dalam Perspektif Global. Unri Press, Pekanbaru.

Kahn, W.A. 1990. Psychological conditions of personal engagement and disengagement at work. Academy of Management Journal, Vol. 33, pp. 692-724.

Kapoor, C., \& Solomon, N. 2011. Understanding and managing generational differences in the workplace. Worldwide Hospitality and Tourism Themes. 3 (4), 308-318.

Koester, A. 2010. Workplace discourse. Continuum International Publishing Group, London.

Macey, Schneider, Barbera, Young. 2009. Employee Engagement, Tools for Analysis, Practice, and Competitive Advantage. John Wiley \& Sons, Chichester,West Sussex, UK., p:8.

Moleong. L. J. 2011. Metode Penelitian Kualitatif. PT. Remaja Rosdakarya, Bandung.

Myers, K., \& Sadaghiani, K. 2010. Millenials in the workplace: A communication perspective on millennials' organizational relationships and performance. Journal of Business and Psychology, 25(2): 225-238 June 2010.

N.I, Ardiansyah \& N.K., Darmasetiawan, 2019. Psychological well-being and work place relations gaps on generational differences, Advances in Social Science and Humanities Research Volume 308. Atlantis Press: Proceeding of $16^{\text {th }}$ International Symposium on Management (INSYMA 2019).

Nusantria, Sandi and Suharnomo, 2011. Employee Engagement : Anteseden dan Konsekuensi Studi pada Unit CS PT. Telkom Indonesia Semarang. Undergraduate thesis, Universitas Diponegoro.

Robert. 2010. Green Marketing Management, South Western Cengage Learning, University of Kentucky.

Simanjuntak, P. Y. 2003. Manajemen Hubungan Industrial. Pustaka Sinar Harapan, Jakarta.

Saydam. 2000. Manajemen Sumberdaya Manusia: Suatu Pendekatan Mikro. Djambaran, Jakarta.

Sugiyono. 2013. Metode penelitian kuantitatif, kualitatif, dan kombinasi (mixed methods). Edisi Keempat. ALFABETA, Bandung.

Tolbize. 2008. Generation differences in the workplace research and training center on community living, University of Minnesota.

Thomas. 2007. A New Measurement Scale for Employee Engagement: Scale Development, 
Pilot Test, and Replication. Academy of Management Proceeding

Wong, M., Gardiner, E., Lang, W., \& Coulon, L. 2008. Generational differences in personality and motivation. Journal of Managerial Psychology. 23 (8), 878-890. 